\title{
Miranda
}

Revue pluridisciplinaire du monde anglophone /

Multidisciplinary peer-reviewed journal on the English-

speaking world

$12 \mid 2016$

Mapping gender. Old images ; new figures

\section{AS - Wyndham Lewis, Pablo Picasso and the Question of Eclecticism}

\section{Annelie Fitzgerald}

URL: http://journals.openedition.org/miranda/8142

DOI: 10.4000/miranda.8142

ISSN: 2108-6559

Publisher

Université Toulouse - Jean Jaurès

\section{Electronic reference}

Annelie Fitzgerald, "AS - Wyndham Lewis, Pablo Picasso and the Question of Eclecticism", Miranda

[Online], 12 | 2016, Online since 29 February 2016, connection on 16 February 2021. URL: http:// journals.openedition.org/miranda/8142 ; DOI: https://doi.org/10.4000/miranda.8142

This text was automatically generated on 16 February 2021.

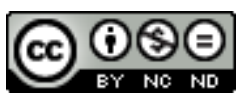

Miranda is licensed under a Creative Commons Attribution-NonCommercial-NoDerivatives 4.0 International License. 


\title{
AS - Wyndham Lewis, Pablo Picasso and the Question of Eclecticism
}

\author{
Annelie Fitzgerald
}

\section{Introduction}

1 In spring 1919 Picasso spent several months in London working with Sergei Diaghilev's Russian Ballet on a production of The Three-Cornered Hat for which he designed the costumes and the stage-sets. ${ }^{1}$ In autumn that year, shortly after Picasso's extended stay in London, Lewis published a pamphlet entitled The Caliph's Design. Architects! Where is Your Vortex?, in which Picasso, described by Lewis as "one of the ablest living painters and draughtsmen" (Lewis 1986, 109), figured prominently; indeed, one chapter of the pamphlet was devoted entirely to a discussion of the Spanish artist's work. ${ }^{2}$ As Sheila Watson has observed, "Lewis's conversation in The Caliph's Design was a conversation with Picasso" (Watson 71). It was also a conversation which Lewis was to pursue, albeit intermittently, throughout his life, and my focus in this article is on the ways in which Lewis portrays and analyses Picasso's prolifically eclectic creativity in the three decades between 1919 and $1950 .^{3}$ I also look more broadly at the concept of eclecticism in Lewis's critical writing of this period. Lewis, of course, was a fearlessly trenchant critic of his artistic and literary peers; his sometimes harsh judgements were, as William Pritchard has put it, "the result of his excellence as a practical critic with superbly equipped ears and eyes" (Pritchard 198). Paul Edwards attributes what he calls the "sharpness" of Lewis's criticisms to "the positive force of his own vision of the highest functions and achievements of art" (Edwards in Lewis 1989, 23). The analysis that follows will draw extensively on the flamboyant and vigorous critical language which Lewis employs to frame his comments on the achievements of Picasso and on the artistic eclecticism which was prevalent in the period of high to late modernism-and, arguably, of early postmodernism. The texture of Lewis's critical writings is characterised by networks of vivid images which reward closer examination, especially given Lewis's tendency as a visual artist to think and argue in such images. This study therefore seeks to 'join the dots' in different critical texts by Lewis in order to reveal an 
underlying trajectory in his thought regarding Picasso and eclecticism; or, to use Lewis's own words, to bring to light his "pattern of thinking" (Lewis 1984, 153) on this subject. I do not attempt to analyse the critical dialogue Lewis conducted with Picasso through his visual art; this has been more than admirably undertaken by Paul Edwards in his monumental work on Lewis (2000) and by Alan Munton and Michael Durman in their study of 2003. In addition, I take Lewis on his own terms and do not attempt to argue with them; that would imply a critical method altogether different from the one I have adopted which, in its focus on the detail of Lewis's aesthetic 'culture', also owes something to Clifford Geertz's practice of "thick descriptions". Thus, through a close analysis of Lewis's critical language I will suggest that his view of Picasso's artistic eclecticism-and his evaluation of the eclectic nature of contemporary art in generalunderwent a significant evolution in this period. In the wake of World War I, Lewis held serious reservations about the artistic value and the ethical and political implications of the eclecticism practised by Picasso and other artists. At this crucial point in history when a new world needed to be built and when, in Lewis's view, a new art could help bring that world into being, Lewis argued that there was "only one mode for any one time, and all the other modes [were] for other times" (Lewis 1986, 96). After World War II and in the last decade or so of his life, however, his attitude towards eclecticism evolved, a change that, as I will show, is reflected in Lewis's subversion of his own critical language.

\section{Art and Life}

2 Lewis's argument in The Caliph's Design had as its premise that the visual arts-amongst which he included architecture-enhanced "gusto and belief" in human existence (Lewis 1986, 80). He stressed the crucial impact that "Design" (Lewis 1986, 10), namely the aesthetics of people's physical surroundings, had on their psychological outlook. ${ }^{4}$ It was his belief that the visual arts also had a fundamental role to play in helping to bring into being what Paul Edwards has aptly characterised as "new modes of consciousness" in the post-war world. ${ }^{5}$ Calling for a radical realisation of the Poundian exhortation to "Make It New", Lewis thought of the new visual language he wanted to see elaborated as "a mode that [would] answer to the great mass sensibility" of the time and reflect what he called the "physiognomy" of modern life (Lewis 1986, 73). This imperative had also formed part of the second vorticist manifesto of 1914-The Caliph's Design, as its subtitle suggests, was conceived by Lewis as a revival of the pre-war vortex -where Lewis had exhorted his fellow artists to produce an art that was "organic with its time" (Fox and Michel 28). ${ }^{6}$ In Lewis's opinion this new artistic idiom had to be developed with a considerable "concentration of effort" and "constructive vision" on the part of both artists and architects (Lewis 1986, 97, 100).

3 The prefatory parable that preceded the main body of Lewis's 1919 pamphlet thus depicted the realisation of such a constructive vision: the transfiguration by fiat of the "heart" of a city-with the term "heart" to be understood in both its spatial and moral senses. The eponymous caliph is a visionary artist-figure who produces a number of radical designs-rather reminiscent of vorticist paintings, we are told-for the transformation of the city of Baghdad. Subsequently these designs are successfully given concrete shape by the caliph's most respected engineer and architect (Lewis 1986, 19-20). The parable can be read as a fantasy on artistic omnipotence and also as a 
fictional realisation of what Tim Hilton has called "that chimerical obsession of modern art, the tabula rasa" (Hilton 73). The caliph's hegemonic dictatorial powers mean that he is able to unleash his creative vitality and transfigure at one sweep both the appearance of the city and the outlook of its inhabitants. As David Peters Corbett has observed, Lewis's writings on art in the immediate aftermath of World War I repeatedly express the need for art begin afresh. ${ }^{7}$ Looking back on his career in a letter of 1940, Lewis was at pains to underline his own radicalism in this regard:

I started life as what is called a 'revolutionary' (in art and letters): a man of the

tabula rasa. I thought everything could be wiped out in a day and rebuilt nearer to

the hearts [sic] desire" (Rose 274)

The prefatory parable in The Caliph's Design thus encapsulated Lewis's belief in the radically transformative power of art and reflected his view that art was, at its most fundamental level, political; that is to say that it was implicated in the workings of the polis and intimately involved in the "effort towards construction" of a better world (Lewis 1986, 107). Lewis's modernism, as Paul Edwards has underlined, consistently sought to transform the lives of ordinary people (Edwards 2000, 218).

\section{The eclectic sensibility}

5 It was in this context, where a renewal and a consolidation of pre-war modernist experimentation and ambition were needed, that eclecticism began to be negatively perceived and represented by Lewis. In his eyes, the nature of the prevailing "eclectic sensibility" (Lewis 1986, 134) was twofold: on the one hand it affected the object or "subject matter" (Lewis 1986, 35) an artist chose to represent in his work (Lewis never espoused total abstraction; in fact he was later to prove a vehement critic of it ${ }^{9}$ ); and on the other it was manifest in the style, the visual idiom in which of a work of art was articulated. ${ }^{10}$

6 As far as the artist's subject matter was concerned, Lewis held that the eclectic sensibility engendered in the artist an "indifference [...] to the life around him" and hence a rather indiscriminate "eclecticism as regards objects" (Lewis 1986, 119, 133). Lewis detected evidence of this in Picasso's work, notably in the cubist penchant for the still life, which Lewis consistently referred to scornfully as the "nature-morte"11. He had complained in 1914 that Picasso's work was too concerned with objects of "inferior significance" (Fox and Michel 44). According to Lewis this form of eclecticism-or "Nature-mortism" (Lewis 1986, 14)-was "a scholarly, receptive and tasteful trend, rather than a creative one"; it was the consequence of an indiscriminate, trivial and "parasitic" interest on the part of artists in the insignificant objects around them (Lewis 1986, 127, 119). Modernist artists had, Lewis would observe in the course of his own gloss on The Caliph's Design in his second autobiography, "battened upon what is silly and ugly, upon the commonplaces and vulgarities of modern everyday existence." Picasso, he opined, "made a fetish almost of a box of matches, an ugly vase or kitchen chair" (Lewis 1984, 170). For Lewis, such eclectic and trivial subject matter-or "tasteless objects" (Lewis 1986, 22)-translated a myopic endorsement of what was rather than a speculative and ambitious interest in what could or should be: "a desire to accept and enjoy: to accept what is already in the world, rather than to put something new there" (Lewis 1986, 128). Such acceptance was evidence of what Lewis called a "Receptive attitude" towards the world in contrast with the "Active and Changing one" 
(Lewis 1986, 123) he advocated. For Lewis at this time, then, eclecticism in art was the reflection of a passive acceptance of the status quo and signified a weak-minded reluctance, or even a refusal, to engage in the acts of criticism, evaluation and discrimination that he believed were required in order to help bring about significant change in what he called "our common life" (Lewis 1986, 119). As well as detecting it in Picasso's work, Lewis regarded this type of indifference to objects or "subject matter" as particularly pronounced in the artistic theories and practices of his Bloomsbury 'enemies', Roger Fry and Clive Bell. ${ }^{12}$ In The Caliph's Design he disagreed with the assertions that Fry had made in his essay "The Artist's Vision" (1919) that "A man's head is no more or less important than a pumpkin"13 and that "Objects of the most despised periods may be grist to his (the artist's) mill" (Lewis 1986, 133). Lewis also took Bell to task for his dilettantish and indiscriminate enthusiasm for insignificant forms, complaining that someone endowed with such the eclectic sensibility of Bell "gushes about everything he sees" (Lewis 1986, 123):

$\mathrm{He}$ is enraptured at the quality of the curious clumsy country print found on the lodging-house wall; at the beauty of cheap china ornaments, a stupid chair, a staring, mean pretentious little seaside house. (Lewis 1986, 123-24)

7 For Lewis, this eclectic sensibility clearly also represented an offshoot of the art-forart's sake aestheticism of the end of the $19^{\text {th }}$ century, the narcissistic, inward-looking nature of which he underlined when he specified that the eclectic artist or critic was "not curious about the object that his mind approache[d], but [was] entirely engrossed with himself and his own sensations" (Lewis 1986, 133). The eclectic sensibility turned the artist's gaze inwards, meaning that he no longer engaged critically with common life. ${ }^{14}$

8 According to Lewis, the prevalent eclectic sensibility was also manifest in an artist's use of different "modes and periods of art" (Lewis 1986, 133) in his work. In The Caliph's Design Lewis emphasised the wide-ranging nature of this sensibility in the following ironically encomiastic enumeration of current-and potential-sources of inspiration for modern art:

Ingres, David, Raphael! Poussin and Claude! Easter Island carvings, El Greco, Byzantium! But there is a vast field yet to cover: the friezes from Nineveh, the heart of Sung, Koyetzu and Sotetzu, the Ajanta caves, Peru, Benin; and the Polar regions have their unhappy dolls, harpoon handles, and the Midnight Sun for some future ballet! (Lewis 1986, 139) ${ }^{15}$

Here, Lewis also 'globalises' what he saw as the "all-inclusive" (Lewis 1986, 77) and indiscriminating nature of the contemporary eclectic sensibility, which covers all corners of the world and many different periods of human history. That Picasso was probably the chief target of this critical salvo is implied by the final word in this catalogue-ballet-since Picasso was involved in at least eight ballet or drama productions between 1916 and 1924 (Warncke 252) and, as already noted, The Caliph's Design was published just a few months after The Three-Cornered Hat had been performed in London in July 1919. ${ }^{16}$

Although Lewis recognised that it was the prerogative of the artist to seek inspiration in the art of different times and places, "tak[ing] what he will" (Fox and Michel 104) from the art of the past, and although he admitted that Picasso's experiments had "refertilised many extinct modes" (Lewis 1986, 109), he worried that, overall, pastiche and the re-appropriation of historical artistic styles represented a distraction from the 
elaboration of the new visual language he was calling for. ${ }^{17}$ For Lewis, as Sheila Watson has pointed out,

Picasso's pastiche, his tireless compulsion to prolong such exercises, his mercurial versatility, made him appear to Lewis as the symptomatic object of a serious scepticism and discouragement in the use of a vitality which he felt should be got out of the studio into life. (Watson 69)

11 Moreover, Lewis was concerned that eclecticism was becoming the dominant language of modern painting and thus an aesthetic dogma. In the foreword to the catalogue of his one-man show "Guns", held at the Goupil Gallery in February 1919, he therefore mockingly distanced himself from what he represented as a fashionable artistic orthodoxy:

I never associated myself to the jejune folly that would tell you one week that a Polynesian totem was the only formula by which the mind of Man [...] might be expressed: the next, that only by some compromise between Ingres and a Chinaman the golden rule of self-expression might be found. (Fox and Michel 104)

At the end of the chapter dedicated to Picasso in The Caliph's Design Lewis claimed that a general tendency to uncritical, "mechanical eclecticism" (Lewis 1986, 115) was the likely outcome of the stylistic eclecticism which Picasso practised with such panache. Picasso's eclecticism provoked in Lewis what could be termed a twofold 'anxiety of influence': an anxiety that Picasso's powerful influence would lead other artists astray by encouraging them to adhere to the fashionable doctrine of eclecticism ${ }^{18}$, and an anxiety that the-in Lewis's view-often frivolous and futile pastiching of the artistic idioms of the past would impede the development of a truly modern mode of painting.

Lewis thus castigated his contemporaries in the visual arts and architecture for lacking the "constructive vision" (Lewis 1986, 100) and the conceptual and creative vigour which were, in his opinion, so urgently required. Eclecticism was one of the symptoms of this weakness. Furthermore, he perceived the eclectic sensibility as a form of painterly navel-gazing and evidence of a crucial failure on the part of artists to see the bigger picture-pun intended!-as Lewis would complain once more in 1934: "The chronic period-tasting of this time serves to screen and hide away the reality" (Lewis 1987, 102; emphasis mine). What can be regarded as Lewis's own appel à l'ordre, the subject of The Caliph's Design, urged artists to eschew the distractions and temptations of eclecticism in order to channel their creative energy into the elaboration of a visual idiom that befitted its time and climate (Lewis 1986, 34). ${ }^{19}$ For Lewis, eclecticism represented a trivial distraction from the (re)constructive task confronting modern art and, by declining to engage with "the form, the data and atmosphere of a time" (Lewis 1986,91 ), those in thrall to the eclectic sensibility were hardly in a position to help change "the form-content of civilised life" (Rose 110). In Lewis's view Picasso and other artists were failing to shoulder the visionary-and revolutionary-responsibilities Lewis believed should be theirs. As Paul Edwards has noted, Lewis considered that Picasso's stylistic eclecticism was "rooted in a pasticheur's temperament rather than in a deeper commitment to a public function for painting" (Edwards 2000, 220), and, as we have seen, in The Caliph's Design, the public function of the artist was depicted in the prefatory parable of the caliph and his transfiguration of Baghdad. ${ }^{20}$ 


\section{The peril of virtuosity}

14 According to Lewis then, the emergence of the eclectic sensibility, along with Picasso's own astounding technical agility at pastiching the styles of his forebears, had shifted, or rather perhaps diminished, the status of art, demoting it from a visionary act to a spectacular action. In other words, Lewis thought that the idea of the work of art as the product of the artist's vision was being superseded by the idea of art as spectacle, as predominantly an impressive technical performance and a lesson in style; largely devoid of meaningful substance relating to common life, it was heading for what he saw as an artistic cul-de-sac, a "Pocket of inorganic experimentation" (Lewis 1986, 12). On many occasions Lewis foregrounded Picasso's astounding technical ability, underlining, for instance, his "immense technical glitter" and his "pyrotechnic displays" (Edwards 1989, 368, 298). At this juncture, it should be recalled once more that Lewis never questioned Picasso's stupendous talent-“it would be impossible to display more ability" (Lewis 1986, 109) - but was concerned about the use to which this talent was put given the immense influence which Picasso exerted over the rest of the art world. In The Caliph's Design we therefore find Lewis mobilizing the same pyrotechnic metaphor to warn that painting was at risk of "fizzl[ing] out in a fireworks of ingenious pseudoscientific stunts, and a ringing of stylistic changes on this mode and on that" (Lewis 1986, 107). This sort of change Lewis would describe a few years later in his essay "Creatures of Habit and Creatures of Change" (1926) as "Change for Change's sake" and "the sterile restlessness of fashion", which he saw as "the rival and substitute of the creative function" (Edwards 1989, 145). Picasso's immense technical ability meant that, for Lewis, he was "an interpreter rather than a creator-a great critic and 'taster', rather than a man who want[ed] to make something new" (Edwards 1989, 292):

I consider Pablo Picasso as a very serious and beautiful performer in oil-paint, Italian chalk, Antoine ink, pastel, wax, cardboard, bread-anything, in fact. But he appears to me to be definitely in the category of executants, like Paganini, or today, Pachmann, or Moiseivitch. (Lewis 1986, 111)

The contentious charge that Picasso was "technically a brilliant performer" (Lewis $1954,28)$ rather than a creator or inventor (Lewis 1986, 53) echoes Lewis's notorious criticism in Time and Western Man (1927) of one of the other "Men of 1914" (Lewis 1982, 9) and one of the principal figureheads of literary modernism, James Joyce. ${ }^{21}$ The Irishman, claimed Lewis, deliberately neglected to think in order not to inhibit his "highly progressive and eclectic craftsmanship" (Lewis 1993, 90). In fact, Joyce cared little about what idea or world-view he expressed, argued Lewis, "so long as he [was] trying his hand at this manner and that, and displaying his enjoyable virtuosity" (Lewis 1993, 88). In Lewis's eyes then, both Joyce and Picasso were "out on a technical spree"22; both the writer and the artist epitomised, and therefore helped perpetuate, what Lewis called the "insolently stylistic" (Edwards 1989, 289) direction the modern movement was taking. Although Lewis appreciated and admired the technical ability displayed in performing such fancy pirouettes he clearly felt that for both Picasso and Joyce they often represented a merely formal distraction from the revolutionary objectives that should be those of art and an abrogation by the artist of his responsibility within the polis. As the very terms which Lewis employs suggest, the "riot of philandering and stylistic tasting" (Lewis 1921, 23) in which Picasso and other practitioners of eclecticism indulged amounted to a form of artistic decadence and a denial of art's political-in the noblest sense of the word-importance in contemporary 
life. In his recent book Modernism and Style, Ben Hutchinson points out that, "in foregrounding its own stylistic surfaces, modernism flirts with a self-destructive narcissism" (Hutchinson 2). It seems clear that Lewis was concerned that his artist and writer contemporaries were succumbing to such a self-destructive "purely formalistic world view" (Hutchinson 7). Technical virtuosity was something that Lewis had identified as early as 1914 as a "perpetual peril" (Fox and Michel, 50) for art, and by 1927 he was complaining that "trivial surface-novelties" were stifling "the true revolutionary impulse" (Lewis 1993, 36). "Revolutionary experiment", he noted,

has almost ceased since the War. By experiment I mean not only technical exercises and novel combinations, but also the essentially new and particular mind that must underlie, and should even precede, the new and particular form, to make it viable. (Lewis 1993, 122; emphasis mine)

\section{Universal philandering}

16 It is important to note that Lewis employs the ethically-freighted term "philander" in connection with Picasso's eclecticism; Lewis reinforced its presence with the revisions he made to the The Caliph's Design in 1939, criticising what he called the "universal philandering" (Fox and Michel 166) he held to be characteristic of the art-world in the aftermath of World War I. Lewis also inveighed against the stylistic eclecticism of contemporary artists in an article titled "What Art Now?" published in the English Review in April 1919, a few months before the first version of The Caliph's Design appeared. ${ }^{23}$ Towards the end of this article, Lewis called for what amounted to a form of artistic monogamy to counter the inconstancy he considered intrinsic to the eclectic mode: "The painter wants one vision, not the philanderer's seven hundred or more" (Edwards 1989, 49). ${ }^{24}$ Lewis seems to have considered Cézanne the paragon of an artistic fidelity to a single vision: Cézanne was, he wrote, a "great monogamist-[a] man of one Muse if ever there was one" (Fox and Michel 166). In the 1919 version of The Caliph's Design Lewis argued that there was only "one mode for any one time" (Lewis 1986, 96), reiterating this conviction in the revised version where he added that artists needed to find a mode allowing them to speak "with one voice, not with a hundred voices" (Fox and Michel 164). The "visual polyphony" (Bernadac 38) displayed by Picasso was, according to Lewis, artistically and ethically suspect in a context that required, in his opinion, "homogeneity and concentration of effort" (Lewis 1986, 100). By referring to Picasso's stylistic fluctuations as "flutterings" (Lewis 1986, 112) and as "pictorial promiscuity" (Fox and Michel 166) Lewis implies the existence of an ethos of stylistic instability and inconstancy that he considered to be an undesirable and "disintegrating" (Lewis 1986, 100) influence in the post-war context.

17 Lewis also drew a contrast between Picasso's prolific and protean creativity and that of Cézanne by means of another revealing cluster of images. While he had implied in 1919 that Picasso's particular form of creative vitality was suspect by describing it as "so adaptable as to be flesh-creeping" (Lewis 1986, 111; emphasis mine), over twenty years later (in his review of the huge Picasso retrospective held at New York's MOMA in 1939-40), Lewis again mobilised the lexeme "creep" in connection with Picasso, this time however deploying it in its botanical sense. Describing Picasso as "a great, luxuriant, voracious plant", Lewis concluded his review by extending the metaphor, remarking that the Spaniard was "a little too much of the liana-the prolific, tropical creeper-rather than the solid giant of the forest-to which description Daumier, or 
Cézanne or Goya answers, but he does not" (Edwards 1989, 300). Lewis's own flamboyant metaphors here articulate one of his characteristic binary oppositions between the painters from the past whom he considered worthy members of the rigorous vortex pantheon and Picasso, whose luxuriant and prodigious "technical agility" (Lewis 1986, 9) he found politically and ethically suspect. The principal implication of this comparison, of course, was that Picasso's art was derivative-more of a performance rather than a creation-and that it was lacking the strength or the rootedness to grow on its own; in other words, Picasso's art was "parasitic" (Lewis 1986, 119). ${ }^{25}$ As a "solid giant", on the other hand, Cézanne seems to embody not only physical strength but also moral probity. ${ }^{26}$ In 1940 Lewis claimed that "Cézanne would have loathed Picasso" (Edwards 1989, 291), and on numerous occasions he represented Cézanne's more sober creativity and his "one-track intelligence" (Lewis 1986, 117) as more valuable than Picasso's unstable and mercurial flamboyancy. ${ }^{27}$ The powerful upward thrust of the Cézanne-like tree reflects Lewis's consistent association of Cézanne with verticality (or uprightness), stability and steadfastness. Indeed, twenty years previously in The Caliph's Design, he had referred to the "monogamist" Cézanne as "volcanic" and as a "vertical source of power" (Lewis 1986, 111). ${ }^{28}$ Cézanne, he had claimed, was "fanatically attached to time and place" in contrast with the eclectic painter or pasticheur who visited different times and places "en touriste" (Lewis 1986, 53). ${ }^{29}$ The liana's prolific creeping and its parasitic dependence on already-existing life forms thus seems to index a form and an ethics of creativity inimical to the particular type of organic art that Lewis was advocating after World War I.

\section{Stylistic flux}

The morphological and ethical difference between the prolific, creeping liana and the "solid giant" of the tree also reflects Lewis's claim that Picasso's artistic talent, in contrast to Cézanne's, was “non-centralized” (Lewis 1986, 112). For Lewis, it seems to have been the non-centralized nature of Picasso's talent that made him so susceptible to change, so "uncertain and mercurial" (Lewis 1986, 110) and placed him at the mercy of his own prolific creativity. ${ }^{30}$ Picasso, however, as portrayed by Lewis, can also be considered as typical of his time precisely because of his susceptibility to change, his eclecticism, his inclination to stylistic variation and, indeed, his "non-centralized talent". In 1927, for instance, Lewis declared that "stability of any sort at all" was hated and was suspect (Lewis 1993, 343). He made this assertion in Time and Western Man (1927), his massive critique of modern society and culture in which he set out to show how the dissolute "time-cult" (Lewis 1993, xix)—which he nevertheless only diffusely defined in the some 450 pages of this work-had become all-pervasive in contemporary western culture and was accelerating its disintegration. As other critics have observed, in Time and Western Man, Lewis contested "the incorporation into art of time" (Edwards in Lewis 1993, 455) and "the fetishization of temporality and the celebration of Bergsonian flux" (Jameson 3) which, to put it briefly, espoused change, relativism, fatalism and subjectivity at the expense of any sort of stability or of a public, commonsense world. Being saturated by what Lewis called the "time mind" (Lewis 1993, xviii) was the principal characteristic of much of the modernism he denounced. As a visual artist Picasso is not a prominent exhibit in Time and Western Man and Lewis only mentions him explicitly twice in its pages; once, as Paul Edwards has pointed out, in order to help illustrate what he saw as the lifelessness of Gertrude Stein's work 
(Edwards 2000, 306). Nevertheless, the terms in which Lewis frames Picasso's eclectic creativity in The Caliph's Design implicitly draw a link between Picasso's creativity and the ethos of the "mercurial flux" (Lewis 1993, 198), the target of Lewis's ire in Time and Western Man. Indeed, in The Caliph's Design, written eight years before he published his magnum opus, Lewis seems to have begun to anticipate and rehearse some of the terms of the argument of Time and Western Man. ${ }^{31}$ For instance, Lewis refers to the eclectic painter as a "Period-taster" and describes Picasso's vitality as "mercurial" (Lewis 1986, $53,111)$. Picasso's eclectic appropriation of different styles from different periods of art history can be considered an early manifestation of the "time mind", as Lewis suggests when he describes the pasticheur as visiting different times and places "en touriste" (Lewis 1986, 53); while the nostalgia for the past which led Lewis to accuse Pound of being "a man in love with the past" (Lewis 1993, 67) in Time and Western Man seems to be anticipated by some of the charges he levelled at Picasso's stylistic eclecticism in 1919.32 Picasso's stylistic variation itself constitutes a form of flux of course, and Lewis later heavily underscored the succession of periods for which Picasso's art had become celebrated:

If anyone ever had 'periods', that artist is Picasso. He is nothing but periods. He is 'periodic' to such a degree that every six months, during one vast period of forty years, has been a period. (Edwards 1989, 295)

The demands of the capitalist marketplace further accentuated the constant change that Lewis thought of as so characteristic of Picasso's work: in the revised version of The Caliph's Design (1939) Lewis claimed that Picasso had "turned painting into an affair of modes", noting that he was producing "a new brood of latest models every few months, which are imposed upon the world by the dealers and their journalistic satellites, just as dress-fashion is" (Fox and Michel 165). Lewis's references to Picasso's periods and modes also suggest that the latter's work has been influenced by the pervasive-and implicitly feminized-“time mind."

In Time and Western Man Lewis also claimed that what he called the "actor mind" (Lewis 1993, 342), a concept that is clearly closely associated with the "time-mind", was the prevalent sensibility in the contemporary world. The "actor-mind", he explained, was "necessarily volatile, love[d] change for change's sake, preferr[ed] parasitically other personalities and other lives to [his] own" and also enjoyed having at its disposal "an infinite number of masks" (Lewis 1993, 342). In the arts, argued Lewis, the actor mind resulted in "prodigious virtuosity" whereby the work of one person "consist[ed] of the schematic juxtaposition of a series of disconnected stylizations; and therefore, since the 'style is the man', of a crowd of men, not one man at all" (Lewis 1993, 342). As Lewis was at this time anxious about the disintegration of what he called the "one personality" (Lewis 1993, 342), he here again unfavourably contrasted plurality and variety with singularity and unity, and although Lewis was once more not explicitly referring to Picasso in this context, the prodigious virtuosity evoked certainly resonates with comments he makes elsewhere on the Spanish artist's stylistic fluctuations. The parallels are striking, for example, between Lewis's critique of the "actor mind", or of the "discontinuous personality" that "wears the coat of one neighbour one day, and of another the next" (Lewis 1993, 342), and the criticisms he directs at Picasso's incessant stylistic changes and at his apparent unwillingness to elaborate the "one mode" (Lewis 1986, 96) Lewis deemed so necessary in the post-war world. ${ }^{33}$ 
21 As it was composed of "a mass of Jekylls and Hydes" (Lewis 1993, 341), the "actor mind's" lack of continuity and integrity could, according to Lewis, have serious ethical and political repercussions: "If yesterday's self is not today's, then also the obligations contracted yesterday are no concern of today's self, and so on" (Lewis 1993, 342). Given Lewis's reservations on this matter, it does not seem coincidental that Lewis had already charged Picasso in 1919 with lacking responsibility, conviction and sincerity, dubbing the eclectic sensibility "an irresponsible, disintegrating" phenomenon and criticising Picasso for being incapable of believing in what he had made (Lewis 1986, 100, 113). Both Picasso's stylistic eclecticism and the "actor-mind" which seems related to it are thus symptoms of a modern ethos that Lewis rejected..$^{34}$ Indeed, in many respects Time and Western Man can be considered a recognition by Lewis of the failure of the revolutionary ambitions for the modern movement that, alongside his powerful and trenchant criticisms of his contemporaries, he had outlined with conviction and exuberance in The Caliph's Design in 1919. The united effort towards construction he had called for in his pamphlet had failed to materialize and, as Lewis saw it, in its place had proliferated a mass of disconnected stylizations: flux, fragmentation and dissipation had triumphed over the stability that was a key concept in Lewis's thought and aesthetics. ${ }^{35}$

\section{The eclectic culture of the transition}

22 As I have suggested, however, Lewis's stance towards eclecticism evolved in the latter part of his life. In 1946, in the immediate aftermath of yet another global conflictwhich much of his writing of the 20 s and 30 s had vainly sought to avert, sometimes under severely misguided premises-Lewis published an essay with the revealing title "Towards an Earth Culture or the Eclectic Culture of the Transition" in which he underlined the radically eclectic and decentralized state of contemporary art and culture:

No unity, either of purpose or technique, is apparent, such as obtained in former epochs, so that it is easy to recognize a work as belonging to such and such a country and period. [...] There is no conceptual centre of our life but a score of centres, no religion or ideology imposes on it an organic pattern; all the patterns are too small and local. (Edwards 1989, 330) ${ }^{36}$

The absent "organic pattern" and the "score of centres" evoked here both recall and contrast with Lewis's previous insistence on the need for art to be "organic" and that there was "one mode for any one time" (Lewis 1986, 96). Furthermore, in this essay Lewis also made the startling claim, given his pronouncements between the wars, that the lack of unity of style or purpose in contemporary art and the fact that it had "no common goal, no common style" was of no importance (Edwards 1989, 334). He averred that the confusion that currently reigned was "a healthy sign" and declared eclecticism, which he now admitted to advocating, to be of "great social value" (Edwards 1989, 331, 335). Although Lewis still referred to Picasso's "mercurial and promiscuous" virtuosity (Edwards 1989, 340), he longer regarded this as deleterious. Indeed, Lewis went so far as to describe eclecticism as "a happy event" and praised Picasso's eclecticism as "catholicity in practice" (Edwards 1989, 331, 337), providing evidence of this in the following description of Picasso's stylistic oscillations:

For ten years (starting about 1917) he led a Jekyll and Hyde life. One day he would paint a classical picture [...] and [...] forge an Ingres with consummate skill. But the 
next day he would paint a strident abstract pattern, with an eye in the middle of the nose-the usual thing. Then the next day back to the classic graces-the pure line, the melting delicacy of exquisite transitions, the noble carriage, le bel air, the large tranquil eye. Then once more, the following morning, the barbaric pattern, the planes screeching and jarring, the mouth eaten by syphilis, the ear in the middle of the cheek. (Edwards 1989, 337)

Taken out of context and read in conjunction with previous statements, this account could easily be misread as critical of Picasso. In fact, the period evoked by Lewis here corresponds more or less to that between the publication of The Caliph's Design in 1919 and Time and Western Man in 1927. In the latter work, as we have seen, Lewis used the characters of Jekyll and Hyde to illustrate the fragmented and discontinuous personality of modern man subject to the depredations of the time cult. In 1946 on the other hand, Lewis invoked Stevenson's characters as evidence of Picasso's "wholesome attitude" (Edwards 1989, 337); in other words, Jekyll and Hyde here signified the opposite of what they had represented in 1927. In 1919, The Caliph's Design had foregrounded and criticized the "non-centralized" nature of Picasso's talent (Lewis 1986, 112), contrasting the Spaniard's stylistic dissipation with the powerfully centralizing figure of the eponymous caliph and with the need for a communal creative force (Lewis 1986, 120). After World War II, however, Lewis seems to have been willing to see the "irresponsible and disintegrating" force of eclecticism, its intrinsic lack of unity, as being superseded by the artist's talent for creating "a personal synthesis" (Edwards 1989, 340):

Even with so mercurial and promiscuous a virtuoso as Picasso, one is never in doubt as to whose hand it is, whether he is being Pompeian for the moment, or despoiling a Zulu kraal of is aesthetic contents. (Edwards 1989, 340) ${ }^{37}$

Indeed, in Lewis's post-World-War-II eyes, the chaos and confusion inherent in the modern world contained the promise of a "new synthesis" and a "universal unity" (Edwards 1989, 340, 335) that would eventually be forged from the eclectic elements currently mixed up in what he called the "common melting pot" (Edwards 1989, 335), itself a striking image, of course, of fluid transformation or of a state of flux. ${ }^{38}$ Lewis predicted that an international, or "cosmic" culture and a new "Earth man" would eventually emerge from the eclecticism (Edwards 1989, 331, 340) that he now regarded as a necessary stage in the development of this new culture:

[...] although you might, like myself, incline always to unity, there will be none until all the fragments of the present world-eruption have been dissolved and a new, this time universal, pattern has emerged. Already glimpses of this future integration may be obtained. We have to live in a chaos. Let us wear our motley to the best advantage, and let us pride ourselves on the number of different patches we display, the more the better. (Edwards 1989, 340)

In admitting his "inclination to unity" here, Lewis recalls the centralising will of the eponymous caliph of 1919; his reference to "wearing motley" resonates-just as it contrasts-with the criticism he made in 1927 of the fashion for wearing different coats on different days and of displaying what he called "disconnected stylizations". Now, however, Lewis was ready to tolerate, and even to praise, the chaotic, fragmentary and heterogeneous present as prefiguring a future synthesis: the current disjointed state of affairs was in fact perceived as evidence of a new form of modernity in gestation. 


\section{From revolution to evolution} a modern cultural revolution to take place overnight, as depicted in the parable of the caliph; the latter's imposition of his designs on Baghdad via the tabula rasa encapsulated Lewis's urge to establish at one sweep a new artistic and political order, and his frustrations with eclecticism are the reflection of the high ambitions he had for modern art. In "Art in Industry", an article from 1934, Lewis was clearly still frustrated by the fact that the modern had not yet succeeded in supplanting the established order and that such "fortresses of conservative prejudice as Burlington House", the home since 1867 of the Royal Academy of Arts, were still standing (Edwards 1989, 242):

The untroubled co-existence [...] of such institutions as Burlington House and of Punch on the one hand, and smoke-blue and jet black vitriolite bookshelves, and sandblasted glass pilasters on the other, is absurd. But it is not only absurd, it is disquieting. For one is inclined to ask whether the sandblasted glass pilasters are not very much surface pilasters for them not to have expelled this enshrined antimacassar at Burlington House. (Edwards 1989, 242) ${ }^{39}$

The "disquieting" situation Lewis depicted in 1934-note also his suspicion that the modern revolution had merely been played out on a superficial level and that radical change had in reality failed to occur-contrasts with the provisional state of tolerant harmony he described in 1946, where the old and the new temporarily yet peaceably coexisted as a prelude to the forthcoming wholesale replacement of the old by the new -the entire process described in the comfortingly familiar terms of a house removal. At the moment, however, they were both

momentarily there under the same roof, all mixed up together like one rather seedy-looking family; the retreating Chippendale mingled with pieces of the incoming proletarian parlour-suite: the pictures of the newcomers going up on the wall before those of the former tenants have been taken down. So Mr Sutherland's (new tenant's) admirable goal-posts crowned with barbed-wire are to be found frame-to-frame with a pastiche of Constable by Steer (old tenant's). (Edwards 1989, 331)

The concept of the tabula rasa, or the clean sweep, is striking in its very absence here. Indeed, the "pleasant and leisurely way" (Edwards 1989, 331) in which this cultural and social hand-over was taking place suggests that Lewis had ultimately come to accept that gradual transition rather than radical rupture, or gentle evolution rather than abrupt revolution, was more in line with humankind's way of working. In this same essay, "Towards an Earth Culture or the Eclectic Culture of the Transition", Lewis professed a similar tolerance of stylistic heterogeneity within an individual work of art, itself a sort of cultural melting pot embodying within itself, in microcosm, the eclectic culture of the transition:

[...] a painting by a British, or American, artist in which the roof of a house reminiscent of the Willow Pattern shelters a figure reminiscent of Altdorfer, dressed in garments which strongly recall those of the Pueblo Indians, with a background that might be a Klee imitated by a Japanese-this would be a sign as solemn, as replete with promise, as the arrival of the dove at the Ark. (Edwards 1989, 331-32)

No longer the sign of cultural decadence, such stylistic eclecticism-even within a single work of art-now presaged an imminent cultural renaissance; the dove of course signalled to Noah that the flood was finally receding and that it was time to found a 
new civilisation. ${ }^{40}$ The serenely optimistic tone of this description and its generous embracing of a plurality of artistic styles, idioms and cultures suggested that by 1946 Lewis had reconciled himself to some extent to what modernism had turned out to be. ${ }^{41}$ "It takes all sorts to make a civilised world", wrote Lewis four years later in 1950, underlining this pluralism: "When there is only one sort we may know civilisation is dead" (Rose 516).

\section{Cosmic culture}

In Lewis's eyes, the most conducive environment for the development of what he called the new "cosmic culture" was post-war America. Lewis, it should be recalled, had been exiled with his wife in North America for the duration of World War II, first vainly trying to make a living as an artist in New York-where an article he wrote about the Picasso retrospective at MOMA "got [him] into great hot water" (Rose 303) ${ }^{42}$-and then living out most of the war in Ontario, Canada. It would hardly be outlandish, I think, to suggest that his experience of living in North America played a crucial role in Lewis's post-war embrace of eclecticism. Indeed, in 1948, two years after the publication of his chapter promoting the "eclectic culture of the transition", Lewis published America and Cosmic Man, a book-length essay in which he developed and explored in greater depth his ideas about cosmic culture and where he identified the United States as "a human laboratory for the manufacture of Cosmic Man" (Lewis 1948, 181). He saw in the United States "the first of the great 'melting pots"' (Lewis 1948, 12); its vast expanse operated like a sort of vortex "into which tumble, and [...] disintegrate, all that was formerly race, class or nationhood" (Lewis 1948, 155). The transition to a new civilisation involved disintegration and, most notably, an embrace of eclecticism and difference. To be American, Lewis argued, was to be "open to all the winds of heavens" and "eclectic, promiscuous-universal" (Lewis 1948, 193). America was the locus par excellence of eclecticism, a place that was home to and could foster immense diversity:

the New World is a mercurial, electric continent of great size and great climatic

range, responsible for alligators in its southern part, and black subarctic squirrels

and sub-zero temperatures in its northern part. (Lewis 1948, 151)

Along with the adjective "mercurial", the zoological and meteorological diversity invoked here recalls the variety of modes and styles embraced by Picasso and other "champions of the eclectic sensibility", an eclecticism criticised and mocked by Lewis earlier in his life as a betrayal of the ambitions of the modern movement (Lewis 1986, 134, 139); the predominant tone here, however, is one of admiration and even awe. ${ }^{43}$

America was an eminently utopian space that Lewis praised in America and Cosmic Man as a "rootless Elysium" (Lewis 1948, 217). Embracing rootlessness and championing "the excellence of what is the opposite of rootedness", Lewis even chose to give one of his chapters the title "The Case Against Roots". In this chapter he claimed that "to be rooted like a tree to one spot" was not a desirable destiny (Lewis 1948, 164-65), again renouncing a form of stability that he had previously embraced and inverting the value of the metaphors that he had employed in 1919 to characterise the creativity of Picasso and Cézanne ${ }^{44}$ Rejecting "the propaganda of rootedness" in the name of the "great cosmic society" to come (Lewis 1948, 169, 170), Lewis asserted his belief that a universalism which would be "in the nature of things eclectic" would supplant the "old style nationalism" (Lewis 1948, 194) and thereby help foster world peace-and 
presumably also increase gusto and belief in life. Lewis was convinced that what was already in progress on the aesthetic and cultural planes would eventually be translated onto the political plane (Edwards 1989, 331-32); art, as we have seen, set in train political change by helping to bring into being "new forms of consciousness".

\section{Conclusion}

Lewis's promotion of rootlessness in his later critical writings thus reflects his embrace of an eclectic pluralism. Towards the end of his life his cultural politics seemed closer to those of Picasso, the "prolific, tropical creeper" and "champion swallower of cultures" (Edwards 1989, 300, 335), than to those of Cézanne, the "solid giant of the forest", and his/its rootedness (Edwards 1989, 300). The blood of this future cosmic man, argued Lewis in 1948, would be "drawn from all the corners of the earth, with no more geographical or cultural roots than a chameleon" (Lewis 1948, 181, 182). As I hope to have shown, this description of cosmic man resonates and contrasts with some of Lewis's earlier, more negative, characterizations of Picasso and the latter's eclectic creativity. Thus, although it was negatively perceived and represented by Lewis at the time, what he criticised as the eclectic sensibility manifest in Picasso's work and elsewhere after World War I subsequently transitioned into an eclectic culture which, in the wake of World War II, Lewis believed heralded a new destiny for both art and humanity. Focusing on the critical lexis and images Lewis employs in his assessments of Picasso and eclecticism helps highlight such shifts in his "pattern of thinking" (Lewis $1984,153)$ and also brings to light noteworthy intertextual connections in his writings. I also hope to have suggested that it pays to read Lewis diachronically: this close reading of Lewis's writings on Picasso and eclecticism shows that Lewis was far less stubbornly and conservatively rooted in his outlook than many of his detractors would have us believe. ${ }^{45}$ In fact, Lewis was constantly re-evaluating modernity and the modern condition, along with his own position within them; his own attitude was indeed the "Active and Changing one" (Lewis 1986, 123) he had advocated so vigorously in 1919.

\section{BIBLIOGRAPHY}

Auden, W. H. and Louis MacNeice. Letters from Iceland. London: Faber and Faber, 1937.

Bernadac, Marie-Laure. "Picasso Cannibale: déconstruction-reconstruction des maîtres." In

Picasso et les maîtres. Exhibition catalogue. Paris: Editions de la Réunion des Musées nationaux, 2008. 37-51.

Campbell, SueEllen. The Enemy Opposite. The Outlaw Criticism of Wyndham Lewis. Athens: Ohio University Press, 1988. 
Corbett, David Peters. “'Grief with a Yard-Wide Grin': War and Wyndham Lewis's Tyros.” Wyndham Lewis and the Art of Modern War. Ed. David Peters Corbett. Cambridge: Cambridge University Press, 1998. 93-123.

Edwards, Paul. Wyndham Lewis, Painter and Writer. New Haven: Yale University Press, 2000.

---. (ed.). Creatures of Habit and Creatures of Change. Essays on Art, Literature and Society, 1914-1956. By Wyndham Lewis. Santa Rosa: Black Sparrow, 1989.

Fox, C. J. and Walter Michel (eds.). Wyndham Lewis on Art: Collected Writings 1913-1956. By Wyndham Lewis. New York: Funk and Wagnalls, 1969.

Geertz, Clifford. The Interpretation of Cultures. Selected Essays. New York: Basic Books, 1973.

Hilton, Timothy. Picasso. London: Thames and Hudson, 1985.

Humphreys, Richard. "Wyndham Lewis and Picasso." Picasso and Modern British Art. Exhibition Catalogue. London: Tate Publishing, 2012. 72-81.

Hutchinson, Ben. Modernism and Style. Basingstoke: Palgrave Macmillan, 2011.

Jameson, Frederic. Fables of Aggression. Wyndham Lewis, the Modernist as Fascist. Berkeley: University of California Press, 1979.

Jolas, Eugene and Elliott Paul. "Suggestions for a new magic.” transition 3 (June 1927): 178.

Lewis, Wyndham. Additional MS 52919. British Library, London.

---. America and Cosmic Man. London: Nicholson \& Watson, 1948.

---. Blasting and Bombardiering. An Autobiography (1914-1926). 1937. London: Calder, 1982.

---. The Caliph's Design. Architects! Where is your Vortex? 1919. Ed. Paul Edwards. Santa Barbara: Black Sparrow, 1986.

---. The Demon of Progress in the Arts. London: Methuen, 1954.

The Enemy No. 1: A Review of Art and Literature (1927). Ed. David Peters Corbett. Santa Barbara: Black Sparrow, 1994 (a).

The Enemy No. 2: A Review of Art and Literature (1927). Ed. David Peters Corbett. Santa Barbara: Black Sparrow, 1994 (b).

---. The Enemy No. 3: A Review of Art and Literature (1929). Ed. David Peters Corbett. Santa Barbara: Black Sparrow, 1994 (c).

---. "Lectures on Art." c. 1944. Drafts, unpublished typescripts. Wyndham Lewis Collection (1877-1975). Coll. No. 4612, Division of Rare Books and Manuscript Collections, Cornell University Library. Box 19.

---. “The Meaning of Ugliness." 1944. Unpublished typescript. Wyndham Lewis Collection (1877-1975). Coll. No. 4612, Division of Rare Books and Manuscript Collections, Cornell University Library. Box 22.

---. "Paris Versus the World." The Dial 71:1 (1921): 22-27.

---. Rude Assignment. An Intellectual Autobiography. 1950. Ed. Toby Foshay. Santa Barbara: Black Sparrow, 1984

---. Time and Western Man. 1927. Ed. Paul Edwards. Santa Rosa: Black Sparrow, 1993.

---. The Tyro. A Review of the Arts of Painting, Sculpture and Design. 1921-22. Ed. Wyndham Lewis. London: Frank Cass, 1970. 
Meyers, Jeffrey. The Enemy: A Biography of Wyndham Lewis. London: Routledge \& Keegan Paul, 1980.

Miller, Tyrus. Time Images. Alternative Temporalities in Twentieth-Century Theory, Literature, and Art. Newcastle: Cambridge Scholars, 2009.

Munton, Alan and Michael Durman. “'Changing our common life': Wyndham Lewis interprets Matisse and Picasso." The Great London Vortex. Modernist Literature and Art. Ed. Paul Edwards. Bath: Sulis, 2003. 134-41.

Penrose, Roland. Picasso. His Life and Work. 1958. London: Granada, 1981.

Pritchard, William. "Literary Criticism as Satire." Wyndham Lewis: A Revaluation. Ed. Jeffrey

Meyers. London: Althone Press, 1980. 196-210.

Rose, W. K. The Letters of Wyndham Lewis. By Wyndham Lewis. London: Methuen, 1963.

Warncke, Carsten-Peter. Pablo Picasso 1881-1973. Part 1: The Works 1890-1936. Cologne: Taschen, 2007.

Watson, Sheila. Wyndham Lewis and Expressionism. 1964. Waterloo (Canada): MLR Editions, 2003.

\section{NOTES}

1. Choreographed by Léonide Massine, The Three-Cornered Hat was first performed at the Alhambra Theatre in London on 22 July 1919.

2. He later revised and included this pamphlet in an anthology of his critical writings which was published in 1939 under the title Wyndham Lewis the Artist: from Blast to Burlington House. In his pamphlet Lewis also noted that "there is nothing [...] with regard to technical achievement that [Picasso] cannot do" (Lewis 1986, 111).

3. One might expect Lewis and Picasso to have met in person given the fact that Lewis lived in Paris between 1904 and 1908 and that they had in common a number of friends, acquaintancesand, in Lewis's case especially, 'enemies'-including Augustus John, Gertrude Stein and members of the Bloomsbury group such as Clive Bell and Roger Fry. Lewis's work was exhibited alongside Picasso's at the Second Post-Impressionist Exhibition of 1912. Despite this spatial, social and professional proximity, it is unlikely that Picasso and Lewis ever actually met; indeed, the Schiff Papers at the British Library include a letter from the early 1920s in which Lewis admits he has never met Picasso (Letter to Violet Schiff, 2 May 1922, Additional MS 52919, British Library). In summer 1907 Lewis missed out on the opportunity to see Picasso's Demoiselles d'Avignon; he happened to be away in Brittany when his friend and mentor Augustus John was invited to Picasso's studio to view the painting (Munton and Durman 135).

4. Lewis later described the aesthetics of one's environment as "the biggest visual fact" (Lewis 1984, 169). In notes for a lecture from the 1940s written towards the end of his extended stay in Canada during World War II, he underlined the psychological impact of the cityscape: "I am convinced that such mean, dispiriting, insignificant, vulgar surroundings are fearfully bad for people. It causes them to be harsh, dull, psychically unattractive. Many modern cities are a sort of death. 1) In Toronto I felt I was not living: scarcely breathing; 2) In Montreal I felt intensely alive: gay and happy" ("Lectures on Art" (c. 1944). Drafts, unpublished typescripts. Wyndham Lewis Collection (1877-1975). Coll. No. 4612, Division of Rare Books and Manuscript Collections, Cornell University Library, box 19).

5. I borrow the term "new modes of consciousness" from Paul Edwards's "Afterword" to The Caliph's Design (Lewis 1986, 147). The artist, Lewis would later explain, made "blueprints" for a new civilisation (Lewis 1984, 135).

6. In this respect Lewis can be considered a 'romantic' in the sense famously expounded by Stendhal in his pamphlet Racine and Shakespeare of 1823. In 1939, on the eve of the World War II, 
Lewis reiterated his conviction that "it is not so good a thing, at the present day, to paint a picture in the manner of Tiepolo, or of Velasquez, or of Manet, as in some new and different manner, more appropriate to the beliefs and conditions obtaining in the twentieth century" (Fox and Michel 303).

7. "The post-war period was to be a blank slate, a cleared ground on which the modernist movement of 1914 could raise itself once more" (Corbett 102). Lewis described the Great War as an insurmountable barrier between the past and the present: "There is no passage back across that to the lands of yesterday"; in his view a "new state of human life" had come into being and needed an art to match it (Lewis 1970, 3).

8. Lewis made a similar claim to be a "pure revolutionary" in a letter of 1937 to the critic Julian Symons: "In me you see a man of the tabula rasa, if ever there was one (cf. The Caliph's Design). My mind is ahistoric, I would welcome the clean sweep" (Rose 246; emphasis in original).

9. See in particular The Demon of Progress in the Arts (1954).

10. The term "style" is Lewis's; he gave a chapter of his pamphlet the title "How the Fact of Style Obstructs", rehearsing in it the familiar argument that style is capable of "transform[ing] anything into gold" (Lewis 1986, 35). In 1934 he reiterated this idea in far more colourful terms: "style is a great magician who can convert a ragged crone into an object of great beauty" (Lewis 1987, 85).

11. The English term 'still life' was perhaps too close an approximation of Lewis's conception of his own vorticist works of art as "electric with a more mastered, vivid vitality" (Fox and Michel 59; emphasis mine). Later, in 1927, Lewis would remark that the "nature mortiste, or painter essentially of still-life, deals for preference with life-that-is-still, that has not much life" (Lewis 1994, 91).

12. Sheila Watson points out that, in his discussion of Picasso's eclectic improvisation, Lewis "observed the striking family likeness between the mood of post-war French studio art and the type of British dilettante mind which he felt announced itself in Roger Fry's essay 'The Artist's Vision"' (Watson 68).

13. Lewis had concluded his essay on Picasso in the first number of BLAST (1914) with the gnomic declaration: "A kettle is never as fine as a man. This is a challenge to the kettles" (Fox and Michel 44).

14. According to Lewis the danger inherent in this position was that art would eventually become "almost totally disconnected from society", with "no direct function in life" and only existing as "a plaything of the intellect" (Lewis 1954, 46).

15. Lewis admired a number of the 'exotic' forms of art referenced here-Koyetzu was blessed in the second number of BLAST, for example-but he believed after World War I that recourse to such exoticism constituted a distraction from the (re)constructive effort that was required.

16. Lewis was later highly critical of the cultural value of Diaghilev's Russian Ballet, devoting a whole chapter to anatomising it in Time and Western Man (1927).

17. According to Lewis contemporary architecture was afflicted with a similar propensity to pastiche, tending to produce "stylistic architectural rubbish" and "silly antique fakes" (Lewis 1986, 48, 11). Too many architects, complained Lewis, were mere "pasticheurs" who built "in Tudor, Italian, or any other style" (Lewis 1986, 43) instead of devoting their creative energies to the invention of a truly modern architectural idiom.

18. Lewis claimed to have focused on Picasso's work in The Caliph's Design in order to combat "the tendencies that must inevitably result from its influence", with which he "entirely disagree[d]" (Lewis 1986, 115). In the revised version of his pamphlet, Lewis justified his focus on Picasso's influence as follows: "Picasso is the recognized pictorial dictator of Paris. So the character and intellect of that one individual signifies a very great deal to all artists at the present time" (Fox and Michel 169). He also dubbed Picasso "a highbrow fashion expert" (Fox and Michel 165). 
19. Paul Edwards observes that Lewis "shared the common desire after the war for a rappel $\grave{a}$ l'ordre, while regarding the particular French form of this desire (the David-Ingres nostalgia) as simply another manifestation of trivially motivated eclecticism" (Edwards 2000, 220).

20. The dichotomy implicit throughout The Caliph's Design between public and private, between outside and inside, would become increasingly pronounced in Lewis's thinking about the arts in the twenties and thirties.

21. Lewis also claimed that Joyce was "not so much an inventive intelligence as an executant" (Lewis 1993, 88).

22. Lewis wrote this in some unpublished notes for a lecture: "Picasso, that notorious revolutionary, is actually a traditionalist born-and-bred, out on a technical spree as it were: as is James Joyce, for that matter, in the field of letters" ("The Meaning of Ugliness" (1944), unpublished typescript. Wyndham Lewis Collection (1877-1975). Coll. No. 4612, Division of Rare Books and Manuscript Collections, Cornell University Library, box 22, p. 61).

23. Note that the title of this article foregrounds the organic relationship between a work of art and the historical period in which it is produced.

24. In the revised version of The Caliph's Design Lewis expressed his concern that an "inconstancy in the scholarly vein might be matched by an inconstancy in the revolutionary" (Fox and Michel 172). His choice of the term "inconstancy" is revealing because it not only links stylistic fluctuation with the possible failure of art to realise its revolutionary potential but also suggests that there is something ethically dubious about eclecticism. Indeed, Lewis had suggested as much at the end of the 1919 version of his pamphlet, in an assertion where the terms "eclectic" and "fickle" are presented as interchangeable: "no good painter has ever been eclectic or very fickle in his manner of work" (Lewis 1986, 142).

25. Lewis described Ezra Pound as a "parasite" in 1927 but conceded that he had "none of the unpleasant characteristics we associate with an organism dependent on others for its habitat and soil" (Lewis 1993, 68).

26. Lewis also credited Cézanne's work with "tremendous sincerity and certainty" (Lewis 1986, 103).

27. "Any faithful discipleship of that master [Cézanne] is sure to be sound art" (Lewis 1986, 14), wrote Lewis approvingly in 1919.

28. Lewis contrasted verticality unfavourably with horizontality in an essay of 1926: "when a creature is unable to ascend in the scale, it always remains to him to move horizontally: and he can always pretend, to himself or others, that this movement is the equal of the other, although evidently it requires an inferior expenditure of energy" (Edwards 1989, 145).

29. In 1927 Lewis criticised Oswald Spengler's notion of the "'historical' mind" using similar terms and for similar reasons: "The pretentious omniscience of the 'historical' intelligence makes of it an eternal dilettante, or tourist. It does not live in [sic], it is en touriste that it tastes this timedistrict, or time-climate, and that" (Lewis 1993, 217).

30. Lewis similarly described Joyce as the victim of an "unorganized susceptibility to influences" (Lewis 1993, 73). He later referred to Henri Bergson as "the mercurial philosopher of flux and movement" (Lewis 1994(b), 38).

31. The passivity and lack of critical acumen that Lewis associated with the eclectic sensibility in The Caliph's Design is echoed in Time and Western Man when Lewis asserts, in his discussion of the "time-philosophy" of Oswald Spengler, that "A truly chronologically or time-minded person knows better than to alter or criticize anything" (Lewis 1993, 216). Lewis criticised Spengler for promoting in The Decline of the West (1918) what he saw as a philosophy of fatalism where human beings were unable to determine the course of history.

32. Echoing the terms of the arguments marshalled in The Caliph's Design, Lewis criticized Ezra Pound for his penchant for recycling the past: Pound was "a great time-trotter", and there was "almost nowhere in the Past that he has not visited" (Lewis 1993, 67, 69). Pound's poetry 
amounted to "a series of pastiches of old french or italian [sic] poetry", and its "novelty consisted largely in the distance it went back, not forward; in archaism, not in new creation" (Lewis 1993, 38).

33. Such changes are also reminiscent of what Lewis described in Time and Western Man as the "series of one-day lives" (Lewis 1993, 13). In The Caliph's Design, Lewis claimed that any talented artist could design "a new mode every week without any difficulty, some new stylistic twist", yet concluded trenchantly: “This is not, however, what is needed” (Lewis 1986, 96).

34. In Lewis's diagnosis, Picasso is, as Tyrus Miller puts it, "a symptomatic figure-an artist of extraordinary technical capacity and creative energy who has set up an aimless liberalism in the governance of his artistic soul" (Miller 89-90).

35. In her extended analysis of Time and Western Man SueEllen Campbell underlines Lewis's belief that "a world view that embraces the stable rather than the changing-a space-world rather than a time-world-is ethically superior, both on the level of the individual and on the level of society" (Campbell 82).

36. The essay appeared, along with a number of reproductions of visual works by Lewis, in The Pavilion: A Contemporary Collection of British Art and Architecture, edited by Myfanwy Evans (London: I. T. Publications, 1946).

37. Roland Penrose has underlined the paradox whereby Picasso's stylistic variability is "characteristic of [his] work, the signature of his personality" (Penrose 244). In Time and Western Man, discussing his own need for a "terra firma" or a clear sense of self in a "boiling and shifting world", Lewis had argued that his own changing-or mercurial?-surface concealed "something fundamental, quite underneath the flux", but that "in no way prevent[ed] my vitality from taking at one time one form, at another another" (Lewis 1993, 132). In his earlier career, then, Lewis appears to have been unwilling to grant that Picasso might resemble him in this respect whereas this seems to be the case in 1946 when Picasso's "hand" seems analogous to the "fundamental something" that lies beneath the flux of appearances.

38. The previously negative associations of the melting pot are underlined in Lewis's 1937 autobiography: "We are all in the melting pot. I resist the process of melting so have a very lively time of it. I know if I let myself melt I should get myself mixed up with all sorts of people I would sooner be dead than mixed into" (Lewis 1982, 15).

39. In another essay of 1939 Lewis argued similarly that "a steel-and-glass writing table cannot cohabit with an escritoire or a grandfather clock" (Fox and Michel 305).

40. On numerous occasions in the 1920s and 1930s Lewis deployed the metaphor of the ark to convey the dissolution he felt was wrought by the culture of the flux: "In such a fluid world we should by all rights be building boats rather than houses. But this essay is a sort of ark, or dwelling for the mind, designed to float and navigate [...] For a very complete and profound inundation is at hand" (Lewis 1926, 26). Here, however, the ark has survived the deluge and Lewis foregrounds the auspicious arrival of the dove.

41. Lewis wrote Time and Western Man to defend the culture he admired and believed in from the cultural, political and economic forces that he considered were conspiring to destroy it. In America and Cosmic Man he explicitly acknowledged that "Western Man" was dead (Lewis 1948, 219). "Cosmic Man" was to replace him and it was to this end that Lewis's efforts were henceforth devoted.

42. First published in the Kenyon Review in spring 1940, the essay is reprinted in Paul Edwards's edition of a selection of Lewis's critical writings on art and culture, Creatures of Habit and Creatures of Change (1989).

43. The phonetic and orthographic proximity of the terms "electric" and "eclectic" raises the interesting possibility that this could even be a revealing typographic error.

44. In "Towards an Earth Culture or the Eclectic Culture of the Transition" Lewis argued that "A man anchoring himself [...] to a particular tribal valley and cultivating a geographical and tribal 
emotion, would be a matter of far greater offence than should he refuse to be chronologically promiscuous" (Edwards 1989, 336). Four years later, Lewis wrote in the same vein: "we should be thankful that we are having our roots loosened, or, better, pulled up. We are not vegetables or trees, although we often rant about our roots as if we were" (Lewis 1984, 100).

45. A verdict encapsulated in Auden's-admittedly early-characterization of Lewis as "That lonely old volcano of the Right" (Auden 233).

\section{ABSTRACTS}

This article examines aspects of Wyndham Lewis's critical writings on Picasso between 1919 and 1950 and on the spirit of eclecticism he associated closely with the Spanish artist. Lewis's writing is permeated by networks of vivid images which reward closer examination, especially given Lewis's tendency as a visual artist to think and argue in such images. I show that Lewis's view of Picasso's artistic eclecticism-and his evaluation of the eclectic nature of contemporary art in general-underwent a significant evolution in the wake of World War II.

Cet article analyse certains aspects des écrits critiques que Lewis consacre à Picasso entre 1919 et 1950, et à l'esprit éclectique qu'il associe étroitement à l'artiste espagnol. L'écriture de Lewis est imprégnée de vives images qui surgissent dans différents textes et qui méritent d'être examinées de plus près, particulièrement en raison de la tendance qu'a Lewis, en tant que peintre lui-même, de recourir à de telles images pour étayer sa pensée. La perspective de Lewis sur l'éclectisme de Picasso-et l'évaluation qu'il effectue de la nature éclectique de l'art contemporain en généralévolue de manière significative à la suite de la deuxième guerre mondiale.

\section{INDEX}

Mots-clés: architecture, art moderne, éclectisme, modernité

Subjects: British painting

Keywords: architecture, eclecticism, modern art, modernity

\section{AUTHORS}

\section{ANNELIE FITZGERALD}

Maître de conférences

Université Toulouse - Jean-Jaurès

annelie.fitzgerald@univ-tlse2.fr 